\title{
Rapid Exocytosis in Single Chromaffin Cells Recorded from Mouse Adrenal Slices
}

\author{
Tobias Moser and Erwin Neher \\ Department of Membrane Biophysics, Max-Planck-Institute for Biophysical Chemistry, Am Faßberg, D-37077, \\ Göttingen, Germany
}

\begin{abstract}
We report here that brief depolarizations such as action potentials trigger exocytosis in thin mouse adrenal slices. The secretory rates obtained in membrane capacitance recordings from chromaffin cells in slices are faster than those observed in isolated cells. Fast exocytosis in slices is attributable to the rapid release of a small pool of vesicles. The pool recovers from depletion with a time constant of $10 \mathrm{sec}$. Recruitment of the rapidly released vesicles is strongly hindered by the fast $\mathrm{Ca}^{2+}$ chelator BAPTA and much less by the
\end{abstract}

slower chelator EGTA. We suggest that these vesicles are located in close proximity to $\mathrm{Ca}^{2+}$ channels. Spatial coupling of $\mathrm{Ca}^{2+}$ entry and exocytosis may be sensitive to cell isolation and culture.

Key words: exocytosis; membrane capacitance measurement; chromaffin; adrenal slice; calcium chelators; calciumsecretion coupling; neuroendocrine; calcium current; secretory depression
Exocytosis is triggered by an elevation in cytosolic $\left[\mathrm{Ca}^{2+}\right]$ in both neuroendocrine cells and nerve terminals (Douglas, 1968; Katz, 1969). Furthermore, just as in presynaptic terminals, action potentials (APs) are physiological stimuli for hormone release in neuroendocrine cells (Kidokoro and Ritchie, 1980; Wakade, 1982; Zhou and Misler, 1995). Nevertheless, there are distinct differences between hormone secretion from isolated neuroendocrine cells and release of transmitters from small clear-cored vesicles at neuronal synapses. For example, catecholamine release from isolated chromaffin cells is only loosely coupled to action potentials (Zhou and Misler, 1995), with latencies of several tens of milliseconds, whereas neurotransmission is highly synchronized (Katz and Miledi, 1965). The majority of the time delay of release in isolated chromaffin cells is attributed to the time required for $\mathrm{Ca}^{2+}$ to diffuse from a $\mathrm{Ca}^{2+}$ channel orifice to the release sites (Chow et al., 1996). On this basis a mean diffusional distance on the order of $300 \mathrm{~nm}$ has been estimated (Klingauf and Neher, 1997). Exocytosis of chromaffin granules can occur very quickly if the $\left[\mathrm{Ca}^{2+}\right]$ at the release site is elevated to a sufficiently high level (Heinemann et al., 1994). In fact, isolated chromaffin cells release a small fraction of granules well synchronized with depolarizing stimuli, with latencies of $<5 \mathrm{msec}$ (Chow et al., 1994). This more synchronous release has been suggested to result from exocytosis of a small population of vesicles located closer to $\mathrm{Ca}^{2+}$ channels (Klingauf and Neher, 1997).

Morphological studies have suggested a polarized phenotype for adrenal chromaffin cells in situ (Carmichael, 1986). Synaptic inputs occur at the neural pole, and exocytosis may take place preferentially at the capillary pole (Carmichael et al., 1989). We

Received Dec. 3, 1996; accepted Jan. 21, 1997.

This work was supported by grants from the Human Frontiers Science Program (RG-4/95B) and the Deutsche Forschungsgemeinschaft (SFB 523) to E. Neher. We thank Drs. Kevin Gillis, Henrique v. Gersdorff, Corey Smith, and C. Matthes for critical feedback on this manuscript. We thank F. Friedlein and M. Pilot for expert technical assistance. We thank Dr. R. J. Bookman for providing the rat chromaffin cell data shown in Figure $3 A$.

Correspondence should be addressed to E. Neher at the above address.

Copyright (C) 1997 Society for Neuroscience 0270-6474/97/172314-10\$05.00/0 were interested in whether chromaffin cells in situ show substantial synchronous secretion, as would be expected if distances for $\mathrm{Ca}^{2+}$ diffusion were short in a specialized region of the cell.

We performed patch-clamp measurements of membrane capacitance $\left(C_{\mathrm{m}}\right)$ (Neher and Marty, 1982) in mouse chromaffin cells in thin slices of adrenal glands and in primary culture. We report here that kinetics of exocytosis is more neuron-like in mouse chromaffin cells in slices than in culture. Cells in our slice preparation typically responded to individual APs with sizable exocytotic capacitance changes $\left(\Delta C_{\text {exo }}\right)$, whereas only one of seven isolated cells showed comparable responses to single APs. Cells in slices secreted more than isolated cells for equivalent $\mathrm{Ca}^{2+}$ current integrals during short step depolarizations. Two different protocols, both evoking secretory depression, were used to demonstrate the existence of a small, rapidly secreted pool of vesicles in slices. The rapid kinetics of secretion in chromaffin cells in slices is suggested to result from close spatial coupling of release sites and $\mathrm{Ca}^{2+}$ channels.

\section{MATERIALS AND METHODS}

Adrenal slice preparation and whole-cell recordings. NMRI mice (4- to 10 -week-old females) were killed by decapitation. After adrenal glands were removed, they were embedded in a $3 \%$ agar solution. The hardened agar block was then glued with cyanoacrylate onto the stage of a slicing chamber. The chamber contained ice-cold bicarbonate-buffered saline (BBS, solution 2). Slices of 100-200 $\mu \mathrm{m}$ thickness were sectioned on a vibrating tissue slicer (Campden Instruments, Cambridge, UK) at a frequency of $6 \mathrm{~Hz}$. After the slices were sectioned, they were immediately transferred into a holding chamber containing oxygenated BBS (solution 1 , continuously bubbled with $95 \% \mathrm{O}_{2}$ and $5 \% \mathrm{CO}_{2}$ ). Slices were kept at $37^{\circ} \mathrm{C}$ for $15 \mathrm{~min}$ and thereafter at room temperature.

For recording, slices were fixed in the recording chamber by means of a grid of nylon threads. After the slices were mounted onto the stage of an upright microscope (Axioscope, Zeiss), the chamber was perfused with bubbled $\mathrm{BBS}\left(95 \% \mathrm{O}_{2}\right.$ and $5 \% \mathrm{CO}_{2}$, solution 1) at a flow rate of 1-2 $\mathrm{ml} / \mathrm{min}$. Usually a cleaning pipette was used to remove loose material from the cell surface. Conventional whole-cell recordings (Hamill et al., 1981) were performed with 3-4 M $\Omega$ pipettes, and an EPC-9 patch-clamp amplifier together with Pulse software (HEKA, Lambrecht, Germany) were used. Usually, gigaohm seals were formed on the nucleus-containing 
region. The access resistances ranged from 5 to $12 \mathrm{M} \Omega$. Stable recordings could be obtained between $15 \mathrm{~min}$ and at least $8 \mathrm{hr}$ after the slicing.

Evoked $\mathrm{Ca}^{2+}$ currents were measured under conditions in which potassium currents were blocked by intracellular $\mathrm{Cs}^{+}$and extracellular d-tubocurarine (Park, 1994). We did not use tetrodotoxin to block sodium channels because it prolongs a transient nonsecretory capacitance change $\left(\Delta C_{\mathrm{t}}\right)$ (Horrigan and Bookman, 1993), which is observed after depolarization of chromaffin cells. Instead, when the whole-cell current was integrated for estimation of the $\mathrm{Ca}^{2+}$ charge $\left(Q_{\mathrm{Ca}}\right)$, the current during the first $1.9 \mathrm{msec}$ was neglected for both preparations. Thus, our $Q_{\mathrm{Ca}}$ estimate presumably missed the activating phase of the $\mathrm{Ca}^{2+}$ current. For $2 \mathrm{msec}$ pulses, therefore, $Q_{\mathrm{Ca}}$ represents mainly the $\mathrm{Ca}^{2+}$ tail current $\left(Q_{\mathrm{Ca}}\right.$ was measured until $1 \mathrm{msec}$ after the end of the depolarization). No leak correction was applied; instead, cells with resting currents of more than $-30 \mathrm{pA}$ were discarded from analysis. Experiments on both preparations were carried out at room temperature.

Isolated chromaffin cell preparation and whole-cell recordings. After they were removed, 8-12 mouse adrenal glands were minced in cold calciumfree saline (Locke's buffer). The tissue was then incubated with collagenase (Collagenase A, Boehringer Mannheim, Mannheim, Germany; catalytic activity $0.97 \mathrm{U} / \mathrm{mg}$ ) in Locke's buffer at a concentration of $3 \mathrm{mg} / \mathrm{ml}$, in a shaking bath at $37^{\circ} \mathrm{C}$ for 15,10 , and $5 \mathrm{~min}$. The tissue was triturated between incubations. The collagenase was then washed, and the resuspended material was filtered through a nylon mesh. After centrifugation, cells were resuspended in culture medium (M199 medium, Biochrom KG, Berlin, Germany) supplemented with penicillin/streptomycin, $10 \%$ FCS, and $1 \mathrm{mg} / \mathrm{ml}$ bovine serum albumin, plated on poly-L-lysine-coated coverslips, and incubated at $37^{\circ} \mathrm{C}$ with $10 \% \mathrm{CO}_{2}$.

Cells were used for experiments starting $16 \mathrm{hr}$ after isolation up to day 2 of primary culture. Chromaffin cells could easily be discriminated from cortical cells and fibroblasts by their round and smooth appearance. Experiments were carried out on an inverted microscope (Zeiss Axiovert 100). An EPC-9 patch-clamp amplifier was used together with PULSE software (Heka, Lambrecht, Germany). The access resistance ranged from 4 to $10 \mathrm{M} \Omega$.

Whole-cell capacitance measurements. After the whole-cell configuration was established, the membrane capacitance was compensated by means of the "C-slow" compensation feature of the EPC-9. Capacitance measurements were performed using the Lindau-Neher technique implemented as the "sine $+d c$ " mode of the "software lock-in" extension of PULSE software. A $1 \mathrm{kHz}, 70 \mathrm{mV}$ peak-to-peak sinusoid stimulus was applied at a DC holding potential of $-80 \mathrm{mV}$.

Estimation of $\Delta \mathrm{C}_{\text {exo }}$. Capacitance changes obtained in mouse chromaffin cells in response to depolarizations show, in addition to stable $C_{\mathrm{m}}$ increments (attributable to exocytosis), a transient, nonsecretory component $\left(\Delta C_{\mathrm{t}}\right)$. Estimation of the exocytotic capacitance change (separation of $\Delta C_{\text {exo }}$ from $\Delta C_{\mathrm{t}}$ ) was performed using three different approaches (Figs. $1 B, 2 A, 3 C)$. In all cases the average prepulse $C_{\mathrm{m}}$ served as baseline.

(1) $\Delta C_{\text {exo }}$ was estimated after decline of $\Delta C_{t}$, either as the asymptote of an exponential fit to $\Delta C_{\mathrm{m}}$ (Figs. $\left.1 B, 4\right)$ or as the $\Delta C_{\mathrm{m}}$ average taken over the time from 700 to $900 \mathrm{msec}$ after the depolarization (Fig. $2 A$, and dotted line in Fig. 3C).

(2) $\Delta C_{\mathrm{t}}$ was measured in response to $5 \mathrm{msec}$ depolarizations late in the experiment after the release probability was lowered by reduction of $\mathrm{Ca}^{2+}$ influx (omission of $\mathrm{Ca}^{2+}$ from the extracellular solution or application of $50 \mu \mathrm{M} \mathrm{Cd}{ }^{2+}$ ) or by exhaustion of secretion by repetitive stimulation. For the purpose of illustration, an exponential fit to the averaged low release probability $\Delta C_{\mathrm{m}}$ traces of a cell was subtracted from early $\Delta C_{\mathrm{m}}$ traces of the same cell in Figure 2, $A$ and $B$. For quantitative analysis, $\Delta C_{\mathrm{t}}$ was estimated by averaging $\Delta C_{\mathrm{m}}$ between 100 and $400 \mathrm{msec}$ after the end of depolarization in low release probability traces. The same averaging time window was used for estimation of $\Delta C_{\mathrm{m}}$ at high release probability early in the experiment. Finally, $\Delta C_{\mathrm{t}}$ was subtracted from the early $\Delta C_{\mathrm{m}}$ estimates to yield $\Delta C_{\text {exo }}$ shown in Figures $3 A, B, C$ (solid line) and 5 . The different $\Delta C_{\mathrm{m}}$ estimates at early and late experimental times are most likely attributable to different amounts of exocytosis, because in the rare cases in which cells did not show $\mathrm{Ca}^{2+}$ influx but had robust voltagedependent $\mathrm{Na}^{+}$currents, there was no such change in $\Delta C_{\mathrm{m}}$ with time (data not shown).

(3) For comparison, we also measured $\Delta C_{\mathrm{m}}$ by averaging over the initial $10 \mathrm{msec}$ after the depolarization and then subtracting $8.3 \mathrm{fF}$ times the peak sodium current amplitude in nanoamperes (a correction term given by Horrigan and Bookman, 1994) (Fig. 2A, dashed line in Fig. 3C). Figure $3 C$ shows that all three approaches result in similar values for responses to short depolarizations.
$\Delta C_{\mathrm{m}}$ estimation and other analyses were performed in Igor software (Wavemetrics, Lake Oswego, OR). Data are given as mean \pm SEM unless indicated otherwise. A paired Student's $t$ test was used for comparison of means.

Potential contamination of the capacitance measurements by electrical coupling of mouse chromaffin cells in situ. In our study only a fraction of mouse chromaffin cells showed electrical coupling, and most of the coupled cells seemed to be connected to only one neighboring cell with low junctional conductance (200-500 pS; T. Moser, unpublished observation). Thus, for calculation of the potential contribution of the neighbors to the capacitance measured in the patch-clamped cell, we assumed that a cell was coupled to one neighbor with a $2 \mathrm{G} \Omega$ resistance. For the high frequency of the sinusoidal excitation voltage used $(1 \mathrm{kHz})$, we can simplify the equivalent circuit of the coupled neighbor cell to an RC circuit consisting of the junctional resistance $\left(R_{j}\right)$ and the membrane capacitance $\left(C_{\mathrm{m}}\right)$. The real and imaginary components of this RC-circuit will contribute very little to the $C_{\mathrm{m}}$ estimation in the patch-clamped cell, because the break frequency of this RC element is $8.6 \mathrm{~Hz}$ (more than 100 times less than the excitation frequency). Thus, assuming a $9 \mathrm{pF}$ neighbor cell coupled with a $R_{j}$ of $2 \mathrm{G} \Omega$, we estimate that the $C_{\mathrm{m}}$ recording would be in error by $<1 \mathrm{fF}$ because of cell coupling.

Recording solutions. The standard BBS (solution 1) used for slice recordings contained $125 \mathrm{~mm} \mathrm{NaCl}, 26 \mathrm{~mm} \mathrm{NaHCO}, 2.5 \mathrm{~mm} \mathrm{KCl}, 1.25 \mathrm{~mm}$ $\mathrm{NaH}_{2} \mathrm{PO}_{4}, 2 \mathrm{mM} \mathrm{CaCl}_{2}, 1 \mathrm{~mm} \mathrm{MgCl}, 10 \mathrm{~mm}$ glucose, $0.2 \mathrm{~mm}$ d-tubocurarine. For reduction of $\mathrm{Ca}^{2+}$ influx, we either omitted extracellular $\mathrm{Ca}^{2+}$ (replacing it with $2 \mathrm{mM} \mathrm{MgCl}_{2}$ ) or added $50 \mu \mathrm{M} \mathrm{CdCl}_{2}$. Our low-Ca ${ }^{2+} \mathrm{BBS}$ (solution 2) was identical to solution 1 except that it contained $0.1 \mathrm{~mm} \mathrm{CaCl}_{2}, 3 \mathrm{~mm}$ $\mathrm{MgCl}_{2}$, and no d-tubocurarine. All BBS solutions were adjusted to $\mathrm{pH} 7.4$ by bubbling with $95 \% \mathrm{O}_{2}$ and $5 \% \mathrm{CO}_{2}$. The standard extracellular solution used for recordings from isolated chromaffin cells (solution 3) contained $150 \mathrm{~mm}$ $\mathrm{NaCl}, 2.8 \mathrm{~mm} \mathrm{KCl}, 10 \mathrm{~mm} \mathrm{CaCl}_{2}, 1 \mathrm{mM} \mathrm{MgCl}_{2}, 10 \mathrm{~mm}$ sodium-HEPES, 0.2 mM D-tubocurarine, $\mathrm{pH} 7.2$.

All pipette solutions contained $145 \mathrm{~mm}$ cesium-glutamate, $8 \mathrm{~mm} \mathrm{NaCl}$, $1 \mathrm{~mm} \mathrm{MgCl} 2,2 \mathrm{~mm}$ magnesium-ATP, $0.3 \mathrm{mM} \mathrm{Na}_{2}$-GTP (Boehringer Mannheim), $10 \mathrm{~mm}$ cesium-HEPES [CsOH was purchased from Aldrich (Milwaukee, WI)]. Pipette solution A contained $200 \mu \mathrm{M}$ EGTA and no added $\mathrm{Ca}^{2+}$. Pipette solutions $(\mathrm{B}, \mathrm{C}, \mathrm{D}$, and $\mathrm{E})$ were all buffered to a $\left[\mathrm{Ca}^{2+}\right]$ of $\sim 300 \mathrm{~nm}$ using mixtures of $\mathrm{Ca}^{2+}$-free and $\mathrm{Ca}^{2+}$-loaded chelator solutions, but they differed in the amount and type of the chelator. Scatchard plot analysis was used to determine the $K_{\mathrm{d}}$ for $\mathrm{Ca}^{2+}$ and the purity of BAPTA to be $220 \mathrm{nM}$ and $98.8 \%$, respectively (the $\mathrm{Ca}^{2+}$ electrode was from Microelectrodes, Londondarry, NH; cesium-BAPTA was from Molecular Probes, Eugene, OR). $\mathrm{Ca}^{2+}$-loaded EGTA was prepared as described in Neher (1988), and its $K_{\mathrm{d}}$ for $\mathrm{Ca}^{2+}$ was assumed to be $150 \mathrm{~nm}$. Pipette solutions $\mathrm{B}$ and $\mathrm{C}$ contained $100 \mu \mathrm{M} \mathrm{Ca}{ }^{2+}$-free EGTA or BAPTA, respectively; D and E included $1 \mathrm{mM} \mathrm{Ca}^{2+}$-free EGTA or BAPTA, respectively. Chemicals were from Sigma (St. Louis, MO) unless stated otherwise. The liquid junction potentials of extracellular solutions against the cesium-glutamate-based internal solutions were measured to be $+10 \mathrm{mV}$ for all extracellular solutions used, and all clamp potentials were corrected accordingly.

\section{RESULTS}

\section{Mouse chromaffin cells in slices secrete in response to single APs}

Patch-clamped mouse chromaffin cells in slices were stimulated with AP-like voltage commands. The AP voltage template used was similar to the average shape of mouse chromaffin cell APs $(n=80)$ recorded from three cells in slices in the current-clamp mode (Fig. 1A). To monitor the secretory response, we measured $C_{\mathrm{m}}$ before and after each stimulus $\left(C_{\mathrm{m}}\right.$ cannot be measured during the depolarization). In each of the seven cells we studied, AP stimulation caused a stable $C_{\mathrm{m}}$ increment after a rapidly decaying $C_{\mathrm{m}}$ transient (for an example, see Fig. $1 B$ ). Although the stable $C_{\mathrm{m}}$ increments most likely represent exocytotic $C_{\mathrm{m}}$ changes $\left(\Delta C_{\text {exo }}\right)$, the initial $C_{\mathrm{m}}$ transient $\left(\Delta C_{\mathrm{t}}\right)$ is probably attributable to a nonsecretory capacitance change caused by gating charge movement of sodium channels (Horrigan and Bookman, 1994). Thus, we could still observe $\Delta C_{\mathrm{t}}$ after rundown of the secretory response as well as after reduction of the voltage-gated $\mathrm{Ca}^{2+}$ entry (see Materials and Methods). Like Horrigan and Bookman (1994), we 
A
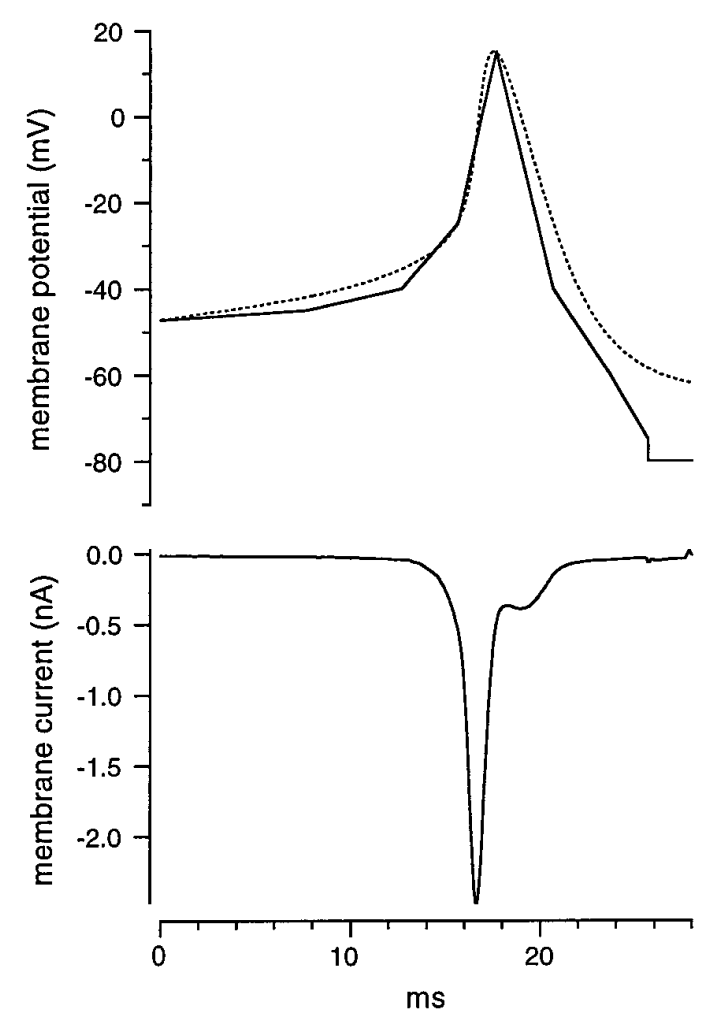

B
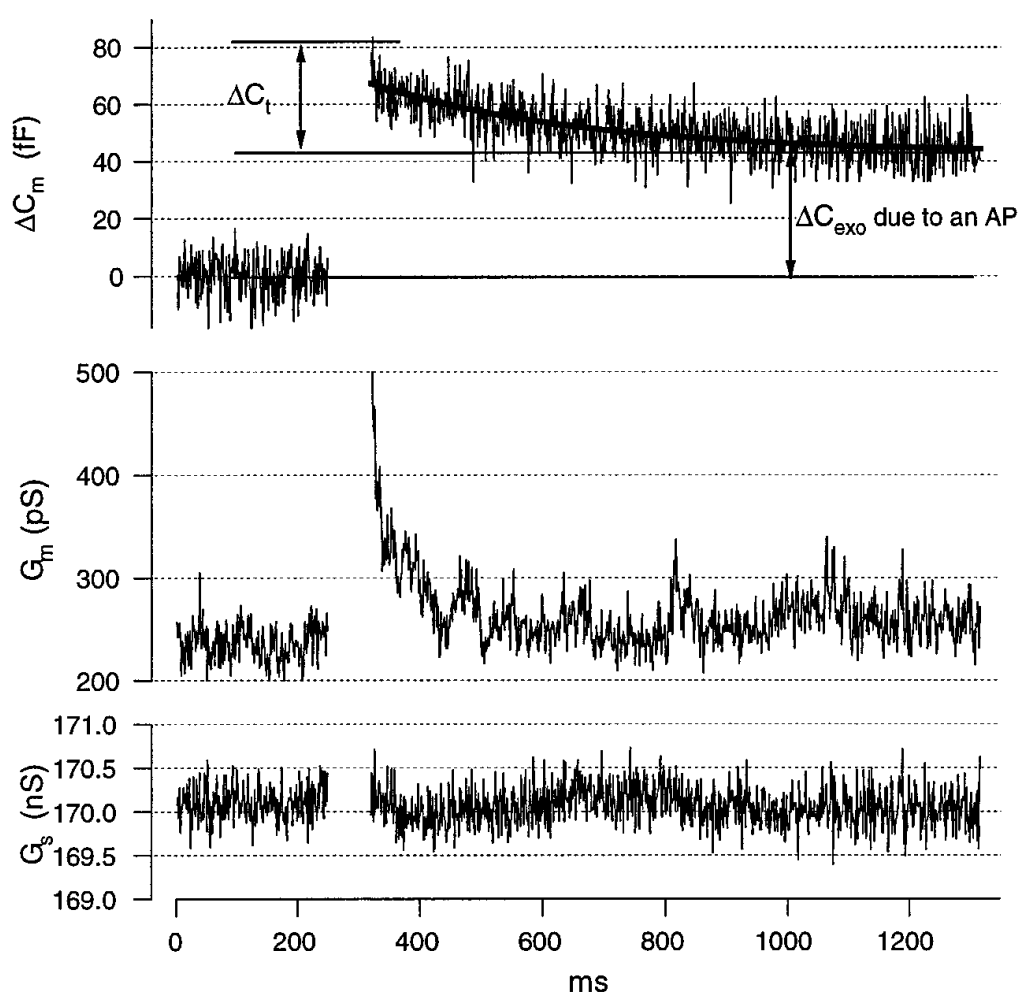

Figure 1. Single AP-like voltage commands cause exocytotic $C_{\mathrm{m}}$ changes in mouse chromaffin cells in slices. $A$ (top), Shape of a representative mouse chromaffin cell AP measured in current clamp with a potassium-based pipette solution (dashed line). The solid line shows the simulated AP-like voltage command used to study secretory responses to single APs. A, (bottom), A typical current response to the AP-like command, with $\mathrm{K}^{+}$currents blocked by a $\mathrm{Cs}^{+}$-containing pipette solution (solution A) and d-tubocurarine in the extracellular saline (solution 1). $B$, Representative $C_{\mathrm{m}}$ measurement before and after application of a simulated chromaffin cell $\mathrm{AP}$ from a holding potential of $-80 \mathrm{mV}$. The top trace displays the AP-induced $C_{\mathrm{m}}$ change. After an initial decay $\left(\Delta C_{\mathrm{t}}\right)$ (for more detail, see Results), a stable $C_{\mathrm{m}}$ increment $\left(\Delta C_{\text {exo }}\right.$ ) remains. The asymptote of the exponential fit to $\Delta C_{\mathrm{m}}$ was used to quantify the $\Delta C_{\text {exo }}$ evoked by the individual APs (approach 1 in Materials and Methods). Middle and bottom traces, Membrane conductance $\left(G_{\mathrm{m}}\right)$ and series resistance $\left(G_{\mathrm{s}}\right)$ are shown to illustrate that there was no major cross-talk among $C_{\mathrm{m}}, G_{\mathrm{m}}$, and $G_{\mathrm{s}}$ estimates.

could abolish $\Delta C_{\mathrm{t}}$ by incubation with dibucaine (200 $\mu \mathrm{M}$, data not shown), which blocks gating charge movement in squid axons (Gilly and Armstrong, 1980). $\Delta C_{\mathrm{t}}$ in mouse chromaffin cells in slices on average decays with a time constant of $\sim 230 \mathrm{msec}$. During this study we used three different approaches to separate exocytotic capacitance changes $\left(\Delta C_{\text {exo }}\right)$ from $\Delta C_{t}$, which result in similar estimates for $\Delta C_{\text {exo }}$ (see Materials and Methods and Figs. $2 A, 3 C)$.

To quantify the exocytotic response to individual APs, we applied five to seven stimuli at intervals of 30-45 sec to seven cells starting 30-60 sec after the beginning of whole-cell recording. After subtraction of the prepulse capacitance, the $\Delta C_{\mathrm{m}}$ traces of a cell were averaged, and $\Delta C_{\text {exo }}$ was estimated as the asymptote of an exponential fit to $\Delta C_{\mathrm{m}}$ (representing the part of $\Delta C_{\mathrm{m}}$ remaining after decline of $\Delta C_{\mathrm{t}}$; approach 1 in Materials and Methods). For the pooled data, an average $\Delta C_{\text {exo }}$ of $16.6 \pm 3.6 \mathrm{fF}(n=7)$ was determined.

Analogous experiments were performed in isolated mouse chromaffin cells. We used $10 \mathrm{~mm}$ extracellular $\left[\mathrm{Ca}^{2+}\right]$, instead of the $2 \mathrm{mM}\left[\mathrm{Ca}^{2+}\right]$ in the experiments in slices, to compensate for the reduction of calcium current caused by the cell isolation (see "Comparison with isolated mouse chromaffin cells" below). Nevertheless, only one of seven cells showed comparable exocytotic responses to single APs, although all of them secreted in response to longer depolarizations (data not shown). The average $\Delta C_{\text {exo }}$ of the seven isolated cells was $4.4 \pm 2.6 \mathrm{fF}$.
For comparison of the observed AP-induced capacitance changes with the results of an amperometric study on APstimulated catecholamine secretion from isolated rat chromaffin cells by Zhou and Misler (1995), capacitance units must be converted to numbers of granules. The size of chromaffin granules varies (diameters range from $\sim 50$ to $500 \mathrm{~nm}$ ) (for review, see Carmichael, 1986), and thus variation is also observed for membrane capacitance increments attributable to fusion of individual chromaffin granules (Neher and Marty, 1982). The mean capacitance of individual chromaffin granules has been measured to be $2.5 \mathrm{fF}$ in bovine chromaffin cells (Neher and Marty, 1982; Chow et al., 1996). Therefore, isolated mouse chromaffin cells would secrete less than two granules per single AP if one assumes an analogous mean capacitance for mouse chromaffin granules. Zhou and Misler (1995) detected less than one release event/AP at low AP frequency $(0.2-1.0 \mathrm{~Hz})$. Considering that the efficiency of their amperometric detector was only $\sim 25 \%$ (Zhou and Misler, 1995), whereas all fusion events are revealed by $C_{\mathrm{m}}$ measurements performed in the present study, the numbers obtained in isolated mouse and rat chromaffin cells seem compatible. On the other hand, mouse chromaffin cells in slices did respond to individual APs with larger capacitance changes, which on average would correspond to approximately six to seven granules/AP (if a mean capacitance of $2.5 \mathrm{fF}$ is assumed for chromaffin granules).

Unfortunately, it was not technically possible to confirm by amperometry that the secretory capacitance changes in response 

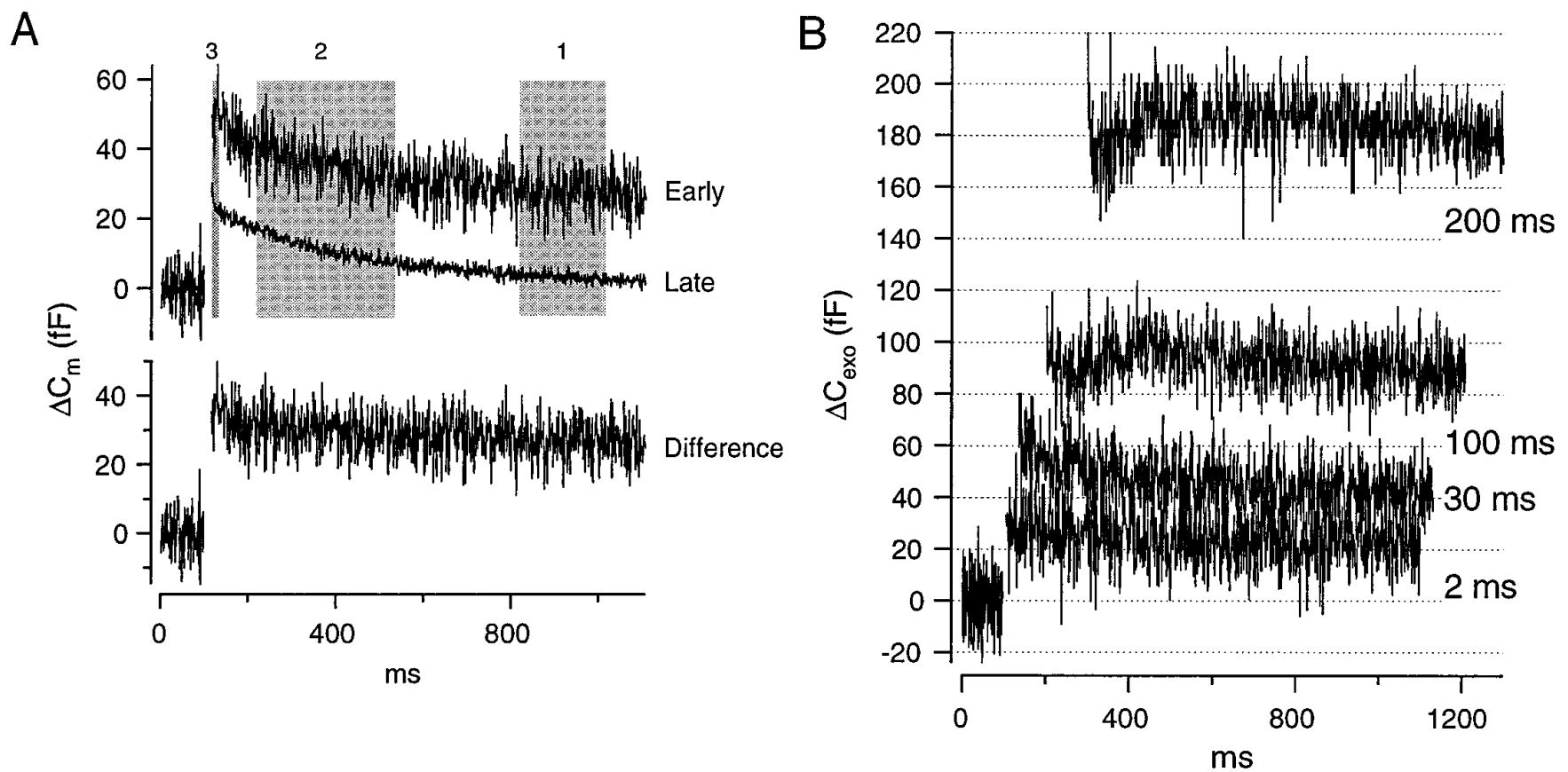

Figure 2. Exocytotic $C_{\mathrm{m}}$ changes in response to short depolarizations are restricted to the time during the stimulation. Starting $30-60$ sec after whole-cell recording, cells were depolarized for different durations 7-15 times, with an interpulse interval of $30 \mathrm{sec}$ (depolarizing potential $0 \mathrm{mV}$ ). Solution $1 \mathrm{was}$ used as external saline. $\left[\mathrm{Ca}^{2+}\right]_{\mathrm{i}}$ was buffered to $300 \mathrm{nM}$ (pipette solution $\mathrm{B}$ or C) by mixing $\mathrm{Ca}^{2+}$-free and $\mathrm{Ca}^{2+}$-loaded buffers to accelerate the vesicle replenishment (von Rüden and Neher, 1993). The holding potential was $-80 \mathrm{mV}$. A (top), Typical capacitance changes in response to a $5 \mathrm{msec}$ depolarization early (top trace: high release probability, 1 response) and late (bottom trace: after exhaustion of secretion, 20 responses averaged) in the experiment. The numbered shaded areas indicate the time periods over which $\Delta C_{\mathrm{m}}$ was averaged for the estimation of $\Delta C_{\text {exo }}$ by approaches $1-3$, as described in Materials and Methods. For this particular cell, the three approaches estimated $\Delta C_{\text {exo }}$ with 27.8 and $27 \mathrm{fF}$ (average over period 1 and asymptote of the exponential fit, respectively: approach 1), $24.4 \mathrm{fF}$ (average $\Delta C_{\mathrm{m}}$ of period 2: 35.9 and $11.5 \mathrm{fF}$ for the early trace and the average of late traces, respectively, approach 2), and $22.9 \mathrm{fF}$ (average $\Delta C_{\mathrm{m}}$ of period 3: $49.5 \mathrm{fF}$; correction term: $8.3 \mathrm{fF} / \mathrm{nA} \times 3.2 \mathrm{nA}$ sodium current, approach 3 ). The bottom of $A$ displays the same early $\Delta C_{\mathrm{m}}$ trace as above after subtraction of the exponential fit to the average of the late traces. $B, C_{\mathrm{m}}$ traces depicting $\Delta C_{\text {exo }}$ of another slice cell in response to depolarizations of 2, 30, 100, and 200 msec duration (from bottom to top) recorded at comparable experimental times. As in the bottom of $A$, an exponential fit to the average $\Delta C_{\mathrm{m}}$ in response to $5 \mathrm{msec}$ depolarizations at low release probability was subtracted from each trace. Both the 2 and the $30 \mathrm{msec}$ responses do not exhibit increases in $C_{\mathrm{m}}$ after the end of the depolarization, indicating that $\Delta C_{\text {exo }}$ is synchronized to $\mathrm{Ca}^{2+}$ entry for short pulses; however, longer depolarizations caused some secretion after the end of $\mathrm{Ca}^{2+}$ entry.

to APs observed in slices represent fusion of chromaffin granules. In particular, there was a large amperometric background current, probably resulting from catecholamines set free from damaged cells (data not shown). From fluctuation analysis of capacitance changes in response to repetitive, brief $(10 \mathrm{msec})$ depolarizations in slices, we have estimated a mean capacitance contribution of single vesicles compatible with values expected for chromaffin granules (T. Moser and E. Neher, unpublished observations). Thus, it is likely that the bulk of the $16.6 \mathrm{fF}$ capacitance change measured in slices in response to individual APs is attributable to exocytosis of chromaffin granules instead of small synaptic-like microvesicles that have been observed in neuroendocrine cells (for review, see Thomas-Reetz and De Camilli, 1994).

\section{High secretory rates in mouse chromaffin cells in slices result from rapid release of a small pool of vesicles}

The rate of secretion is commonly modeled as the product of the number of release-ready vesicles and the $\mathrm{Ca}^{2+}$-dependent rate constant of secretion (Thomas et al., 1993; Heinemann et al., 1994). Thus, high secretory rates can be obtained by a large pool of fusion-competent vesicles and/or by fast release kinetics. The existence of a distinct depletable pool of vesicles is suggested by the observation that the secretory rate drops despite continued stimulation. This secretory depression is commonly interpreted as depletion of a pool of fusion-competent vesicles, which cannot be refilled sufficiently fast to maintain rapid secretion. We used two protocols designed to deplete pools to characterize the kinetic components of depolarization-induced secretion in mouse chromaffin cells in slices.

\section{Protocol 1: secretory responses to $\mathrm{Ca}^{2+}$ current injections of different duration}

Ideally, the study of release kinetics would include measurements of the secretory rate throughout the time of stimulation. Then, in principle, increasing the duration of the stimulation (depolarization-induced $\mathrm{Ca}^{2+}$ current injection) should lead to a drop in secretory rate, indicating pool depletion. However, voltage-dependent conductances make $C_{\mathrm{m}}$ measurements unreliable during the depolarization. In addition, amperometric measurements of catecholamine release, which can be performed during a depolarization, are problematic in slices (see above).

Instead, we reconstructed the relation between secretory response and duration of $\mathrm{Ca}^{2+}$ current injection by measuring the $\Delta C_{\text {exo }}$ in response to step depolarizations (to $0 \mathrm{mV}$ ) of different durations. This protocol has been used previously to study secretion in bipolar terminals (von Gersdorff and Matthews, 1994), isolated rat chromaffin cells (Horrigan and Bookman, 1994), bovine chromaffin cells (Gillis et al., 1996), and nerve terminals in thin slices of the neurohypophysis (Hsu and Jackson, 1996).

Pulses of different duration were applied in random order. Thirty seconds were allowed for recovery between the depolar- 

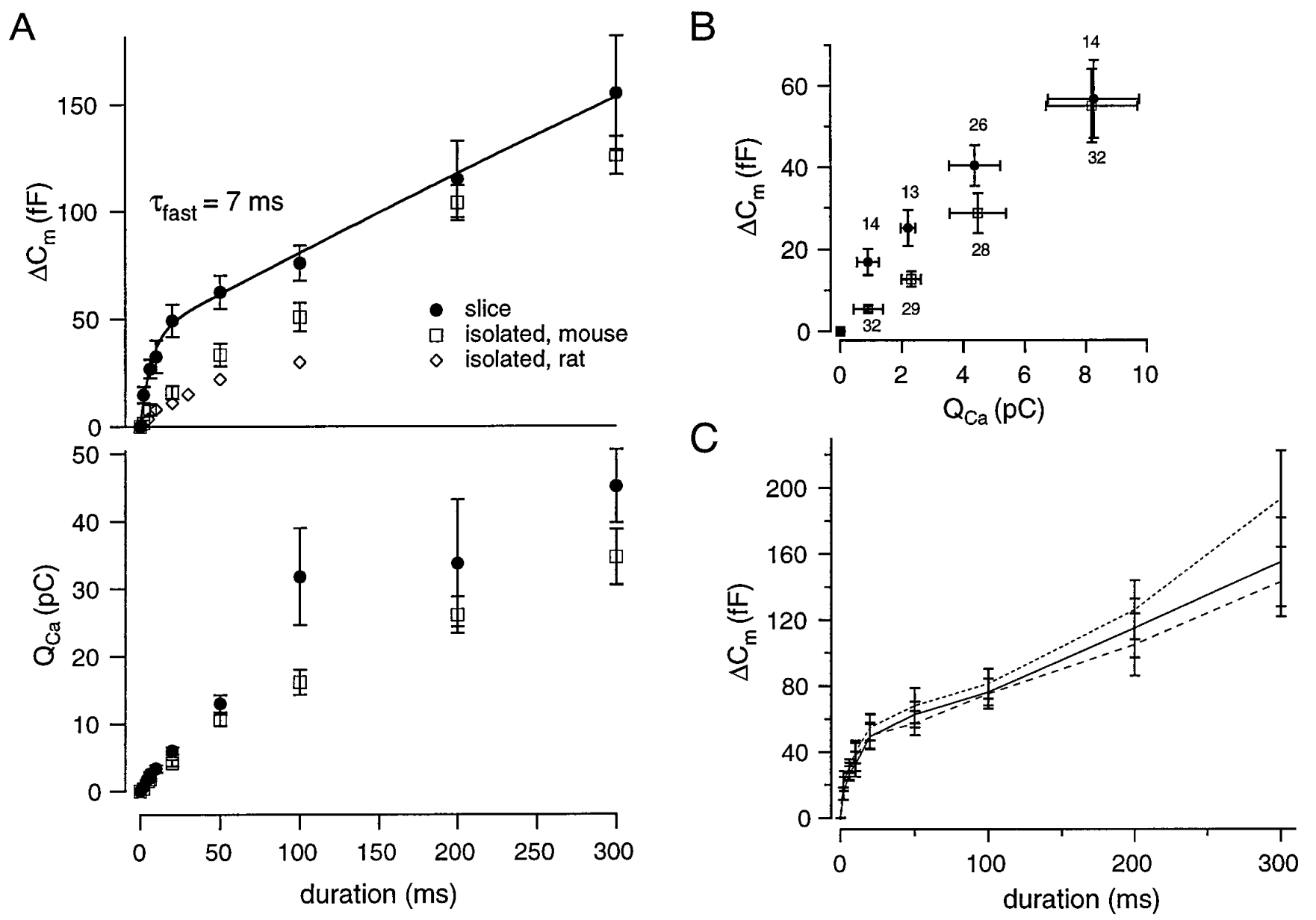

Figure 3. Mouse chromaffin cells in slices show a biphasic rise of $\Delta C_{\text {exo }}$ with increasing duration of $\mathrm{Ca}^{2+}$ current injection. $A$ (top), The filled circles represent pooled data of 10 slice cells with $\Delta C_{\text {exo }}$ estimated by approach 2 in Materials and Methods. For convenience these data were fitted by a double exponential (solid line). The slow secretory component, however, did not saturate with our maximal stimuli. The empty squares plot the $\Delta C_{\text {exo }}$ versus pulse duration data of 20 isolated mouse chromaffin cells. No clear separation into two secretory components was observed. Experiments were carried out as described above (pipette solution B), except that an external $\left[\mathrm{Ca}^{2+}\right]$ of $10 \mathrm{~mm}$ was used. The $\Delta C_{\text {exo }}$ versus pulse duration data obtained from isolated rat chromaffin cells by Horrigan and Bookman (1994) are displayed for comparison (diamonds). Bottom, A plot of $Q_{\mathrm{Ca}}$ versus pulse duration demonstrates that for short depolarizations, $Q_{\mathrm{Ca}}$ rises linearly with increasing pulse duration for both preparations. Furthermore, it shows that the $Q_{\mathrm{Ca}}$ values of slice (filled circles) and isolated (empty squares) cells more or less overlap for short pulses. $B$, The same $\Delta C_{\text {exo }}$ data as in Figure $3 A$ were related to their corresponding $\mathrm{Ca}^{2+}$ current integrals $\left(Q_{\mathrm{Ca}}\right)$. The filled circles represent pooled and binned data from slice experiments. The data for isolated mouse cells are displayed as empty circles. Note that the $\Delta C_{\mathrm{exo}}-Q_{\mathrm{Ca}}$ relation is displayed only for small $Q_{\mathrm{Ca}}$ values (where a difference between both preparations was observed). The numbers of data points per bin are printed above and below the graph for slice and isolated chromaffin cells, respectively. The vertical bars are SEM for $\Delta C_{\text {exo }}$ values, whereas the horizontal bars indicate SD of binned $Q_{\mathrm{Ca}}$ values. $C$, The different lines represent $\Delta C_{\text {exo }}$ data from the same experiments in slices as those analyzed in Figure $3 A$, estimated by three different approaches (see Materials and Methods and Fig. $2 A$ ). The dashed line (approach 3 in Materials and Methods) represents early $\Delta C_{\text {exo }}$ estimates, whereas the solid line (approach 2) and the dotted line (approach 1) result from later measurements after the pulse. This figure demonstrates that all three approaches give quite similar $\Delta C_{\text {exo }}$ estimates at short depolarizations. The discrepancy between the estimates at 200 and $300 \mathrm{msec}$ pulse durations is most likely attributable to some "post-pulse" secretion.

izations. In the course of the experiments, decline of $\Delta C_{\text {exo }}$ and $\mathrm{Ca}^{2+}$ currents was observed for all pulse durations, which we interpreted as run-down (Augustine and Neher, 1992; Burgoyne, 1995). Interpretation of recent results has suggested that after decline of $\Delta C_{\text {exo }}$ attributable to run-down, secretion in a different kinetic mode may persist (threshold-type secretory mode) (Seward and Nowycky, 1996).

Figure $2, A$ and $B$, shows representative $\Delta C_{\mathrm{t}}$-corrected responses to pulses of different length and demonstrates that for short stimuli, the exocytotic capacitance change occurred only during the stimulation. Therefore, even when $\Delta C_{\text {exo }}$ was measured at different times after short depolarizations (see Materials and Methods and Figs. $2 A, 3 C$ ), it could be interpreted as the exocytotic capacitance change during the time of depolarization.
The highest secretory rate (calculated as $\Delta C_{\text {exo }}$ /pulse duration) was observed for the shortest $(2 \mathrm{msec})$ depolarizations, indicating a very short delay of secretion to the onset of the stimulus. On average, 2 msec depolarizations resulted in a $\Delta C_{\text {exo }}$ of $14.7 \pm 3.7$ $\mathrm{fF}$ (nine depolarizations in three cells), which corresponds to a maximal secretory rate of $\sim 7300 \mathrm{fF} / \mathrm{sec}$.

The top of Figure $3 A$ (filled circles) shows the biphasic rise of $\Delta C_{\text {exo }}$, with increasing pulse duration in mouse chromaffin cells in slices (pooled data from 10 cells). The fast component of a double exponential fit to the data had a time constant $\left(\tau_{\text {fast }}\right)$ of $\sim 7 \mathrm{msec}$ ( $n=10$ cells, 112 depolarizations). The observed drop in the secretory rate could be attributable to depletion of fusioncompetent vesicles or result from lessening of the stimulus intensity (for example, because of $\mathrm{Ca}^{2+}$ current inactivation). The 


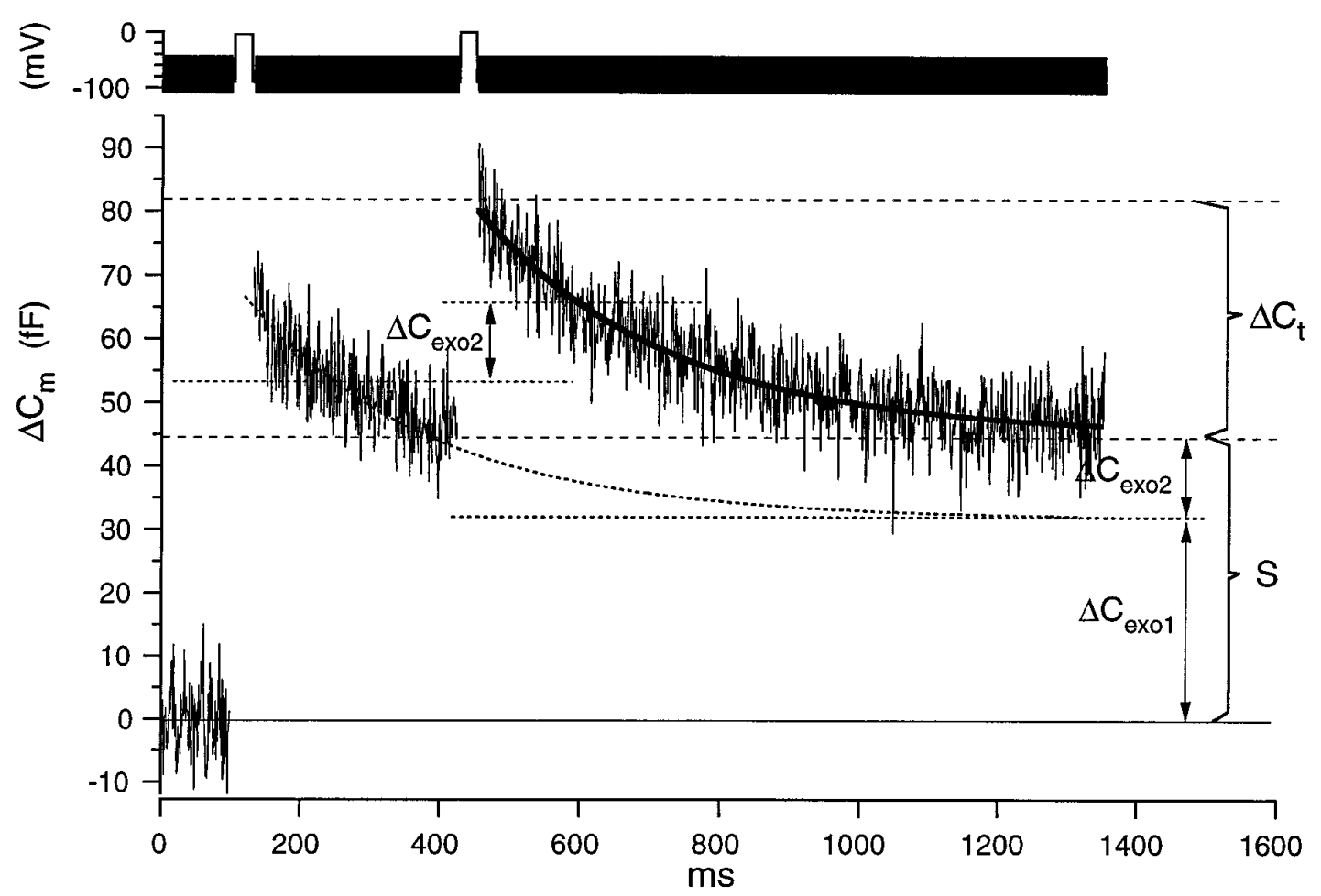

Figure 4. Secretory depression of slice cells is obtained with a pair of $20 \mathrm{msec}$ depolarizations. This figure shows a representative $\Delta C_{\mathrm{m}}$ trace in response to a pair of $20 \mathrm{msec}$ depolarizations (to -6 and $0 \mathrm{mV}$ respectively; see top panel for illustration of the voltage-clamp protocol). Pipette solution B and external solution 1 were used. The sum response $(S)$ to both stimuli was measured as the asymptote of an exponential fit (solid line) to $\Delta C_{\mathrm{m}}$ after the second depolarization. The nonexocytotic $\Delta C_{\mathrm{t}}$ makes direct separate measurement of the exocytotic responses to the first and second depolarization $\left(\Delta C_{\text {exo1 }}\right.$ and $\Delta C_{\text {exo2 }}$ ) difficult. Here, $\Delta C_{\text {exo2 }}$ was estimated as the difference of $\Delta C_{\mathrm{m}}$ averages over the initial $300 \mathrm{msec}$ after the second and the first depolarization, respectively. $\Delta C_{\text {exo1 }}$ was then calculated as $S-\Delta C_{\text {exo2. }}$. This analysis relies on the assumption that the nonsecretory transient $\left(\Delta C_{\mathrm{t}}\right)$ is the same after the first and the second depolarization. This is reasonable, because $\Delta C_{\mathrm{t}}$ saturates for depolarizations as short as 5 msec (Horrigan and Bookman, 1994). For illustration, the exponential fit to the $\Delta C_{\mathrm{m}}$ trace after the second depolarization in addition was overlayed onto the $\Delta C_{\mathrm{m}}$ segment after the first pulse (dashed line).

integrals of the $\mathrm{Ca}^{2+}$ currents $\left(Q_{\mathrm{Ca}}\right)$ are plotted as a function of the pulse length in the bottom of Figure $3 A$ (filled circles). The slope of this plot (which is the average calcium current) does not decline for short pulses even if durations are much longer than $\tau_{\text {fast }}$. Thus, the observed drop of the secretory rate is most likely attributable to depletion of available vesicles rather than to $\mathrm{Ca}^{2+}$ current inactivation. Therefore, the fast component is interpreted as secretion from a limited pool of vesicles, with $\tau_{\text {fast }}$ being the time constant for pool depletion $(7 \mathrm{msec})$ and its amplitude of $\sim 42 \mathrm{fF}$ representing the pool size. Similar results were obtained in five mouse chromaffin cells in slices that were dialyzed with pipette solution A, which contained $200 \mu \mathrm{M}$ free EGTA without added $\mathrm{Ca}^{2+}$ (data not shown).

The slow secretory component apparent in the $\Delta C_{\mathrm{m}}$ versus pulse duration plot could be fitted equally well by a line or a slow exponential. The slope of the best fit line between 20 and 300 $\mathrm{msec}$ is $\sim 270 \mathrm{fF} / \mathrm{sec}$. Interpretation of this component is complicated by two observations. Secretion often persists after the end of long depolarizations (Fig. $2 B$ ), such that for longer pulses the rise of the $\Delta C_{\text {exo }}$ estimates with increasing pulse duration cannot be easily interpreted as secretory rate. Also, the bottom of Figure $3 A$ shows that $\mathrm{Ca}^{2+}$ current inactivation is significant for long pulses.

\section{Comparison with isolated mouse chromaffin cells}

Figure 3 also presents data obtained from 20 isolated mouse chromaffin cells (empty squares) in experiments analogous to those performed in slices. Again, $10 \mathrm{~mm}$ extracellular $\left[\mathrm{Ca}^{2+}\right]$ was used for isolated cells. In most of the isolated cells, short depolarizations ( $<50 \mathrm{msec}$ ) caused much less secretion than in slices; however, longer stimuli ( $>100 \mathrm{msec})$ gave similar $\Delta C_{\text {exo }}$ values for the two preparations. The highest secretory rate was observed for 5 msec depolarizations, which on average caused $\Delta C_{\text {exo }}$ of $7.6 \pm$ $2.52 \mathrm{fF}$ ( $n=46$ responses from 20 cells), corresponding to a secretory rate of $\sim 1300 \mathrm{fF} / \mathrm{sec}$. Responses of isolated mouse chromaffin cells to short depolarizations were similar to those obtained from isolated rat chromaffin cells (diamonds in Fig. $3 A$, taken from Horrigan and Bookman, 1994) or from isolated bovine chromaffin cells (Gillis et al., 1996).

The bottom of Figure $3 A$ shows that isolated mouse chromaffin cells, on average, have smaller $\mathrm{Ca}^{2+}$ currents despite the higher extracellular $\left[\mathrm{Ca}^{2+}\right]$ (10 vs $\left.2 \mathrm{~mm}\right)$. Nevertheless, a plot of $\Delta C_{\text {exo }}$ versus $Q_{\mathrm{Ca}}$ (Fig. $3 B$ ) depicts that cells in slices still secrete more for a given amount of $\mathrm{Ca}^{2+}$ influx for small $Q_{\mathrm{Ca}}$ values. The difference between mean $\Delta C_{\text {exo }}$ values of slice and isolated cells was statistically significant at $Q_{\mathrm{Ca}}$ values of $0.9 \mathrm{pC}$ and $2.2 \mathrm{pC}$ ( $p<0.01$ and $p<0.02$, respectively). At higher $Q_{\mathrm{Ca}}, \Delta C_{\text {exo }}$ values from both preparations were hard to distinguish statistically.

\section{Protocol 2: secretory responses to pairs of depolarizing pulses}

To obtain a second estimate for the number of rapidly releasable vesicles (pool size), we further studied secretory depression using a paired-pulse protocol. We applied short depolarizations (20 msec, $\sim 3 \times \tau_{\text {fast }}$, see above; interval between both stimuli: 300 

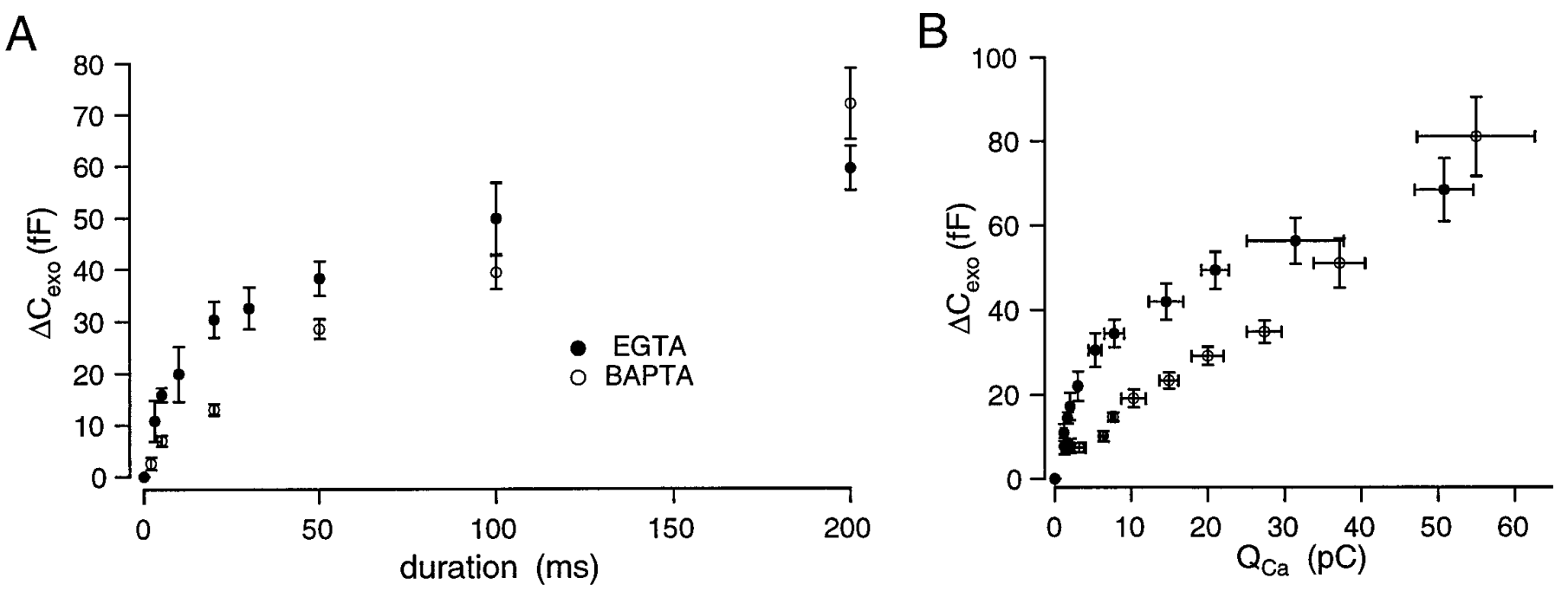

Figure 5. The fast secretory component in mouse chromaffin cells in slices is strongly reduced by BAPTA but much less by EGTA. Experiments were performed similarly as described in Figure 2. Stimulation was started $\sim 60 \mathrm{sec}$ after the whole-cell configuration was established. $\Delta C_{\text {exo }}$ values were estimated by approach 2 in Materials and Methods. For both pipette solutions (D and E), $\left[\mathrm{Ca}^{2+}\right]$ was adjusted at $\sim 300 \mathrm{~nm}^{-}$by mixing Ca ${ }^{2+}$-free and $\mathrm{Ca}^{2+}$-loaded buffers. The holding potential was $-80 \mathrm{mV} . A, \Delta C_{\text {exo }}$ versus pulse duration plot of pooled data from experiments with either $1 \mathrm{~mm}$ free EGTA ( filled circles; $n=10$ cells; solution D) or 1 mM free BAPTA (empty circles; $n=10$ cells; solution E). Experiments were carried out in the same slice preparations for both conditions (five different preparations). In the BAPTA-buffered cells, short depolarizations caused much less secretion than in those dialyzed with EGTA. With longer pulses, however, the secretory responses under both buffering conditions were comparable or even larger with BAPTA (possibly because of the lessening of $\mathrm{Ca}^{2+}$ channel inactivation). $B$, The same $\Delta C_{\text {exo }}$ data as in $A$ were plotted against their corresponding Ca ${ }^{2+}$ current integrals $\left(Q_{\mathrm{Ca}}\right)$. The raw data were arbitrarily binned; vertical bars are SEM of $\Delta C_{\text {exo }}$, and horizontal bars are SD of $Q_{\mathrm{Ca}}$. The right-most BAPTA point indicates that the higher $\Delta C_{\text {exo }}$ values at longer pulse durations were at least partly attributable to larger $\mathrm{Ca}^{2+}$ currents in the BAPTA-buffered cells.

msec) to preferentially recruit vesicles with fast-release kinetics. Starting 30-60 sec after whole-cell recording, dual pulses were applied with intervals of at least $30 \mathrm{sec}$ to allow replenishment of fusion-competent vesicles.

Figure 4 shows a typical $\Delta C_{\mathrm{m}}$ trace and illustrates the analysis. Using the sum $(S)$ of the secretory $C_{\mathrm{m}}$ responses to the first $\left(\Delta C_{\text {exo1 }}\right)$ and second $\left(\Delta C_{\text {exo2 }}\right)$ stimulus and the ratio $(R)$ of $\Delta C_{\text {exo2 }}$

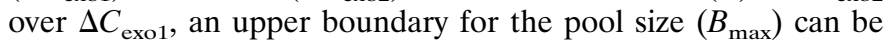
calculated according to:

$$
B_{\max }=s /\left(1-\mathrm{R}^{2}\right),
$$

if depression is achieved $[R<1$; see Gillis et al. (1996) for derivation].

The actual pool size would be given exactly by Equation 1 if both stimuli released the same fraction of the pool of releasable vesicles. Here, the depolarizing potentials were adjusted to match the $Q_{\mathrm{Ca}}$ values of both pulses. Using potentials of $-6 \mathrm{mV}$ and 0 $\mathrm{mV}$ for the first and second pulses, respectively, the ratio $Q_{\mathrm{Ca} 2} /$ $Q_{\mathrm{Ca} 1}$ was $1.05 \pm 0.04$ (21 double pulses in seven cells). The second $\mathrm{Ca}^{2+}$ injection of the dual pulse, however, presumably caused a higher and spatially more extended rise of $\left[\mathrm{Ca}^{2+}\right]_{i}$ than the first pulse, because of residual $\mathrm{Ca}^{2+}$ and submembrane "buffer depletion" (or saturation) remaining $300 \mathrm{msec}$ after the first stimulus. In terms of the kinetic pattern revealed by the $\Delta C_{\text {exo }}$ versus pulse duration plot, we assume that the second depolarization recruited not only vesicles involved in the fast secretory component but also those comprising the slower phase of secretion. This assumption is supported by the finding that a second pulse several seconds after the first actually gave a smaller response than a pulse that followed the first depolarization by only $300 \mathrm{msec}$ (Fig. 6). It is therefore likely that $B_{\max }$ overestimates the actual pool size (hence the "max" notation). This may not be the case if shorter pulses are used in the dual-pulse protocol. Here, $B_{\max }$ is taken as an upper boundary for the size of the pool. $\Delta C_{\text {exo1 }}$, on the other hand, is a reasonable lower boundary.

In all seven cells analyzed, secretory depression $(R<1)$ was observed in the majority of the pulses $(R=0.60 \pm 0.06 ; n=21$ dual pulses from seven cells). The mean $\Delta C_{\text {exo1 }}$ was $31.7 \pm 4.1 \mathrm{fF}$, and the mean $\Delta C_{\text {exo2 }}$ was $17.6 \pm 2.4 \mathrm{fF}$. Three of twenty-one dual pulses were excluded from the $B_{\max }$ estimation because their $R$ was $>0.8$. The average $B_{\max }$ was then $73.1 \pm 10.7 \mathrm{fF}$. Thus, the dual-pulse analysis (in this set of experiments) indicated a size of the pool of rapidly releasable vesicles between 31.7 and $73.1 \mathrm{fF}$.

\section{The fast secretory component in slices is more sensitive to BAPTA than to EGTA}

In the case of close spatial coupling of $\mathrm{Ca}^{2+}$ channels and release sites, secretion should be more sensitive to intracellular application of fast $\mathrm{Ca}^{2+}$ chelators like BAPTA than to slow $\mathrm{Ca}^{2+}$ chelators like EGTA (Adler et al., 1991). The rapid-release kinetics in mouse chromaffin cells in slices prompted us to test the effects of $1 \mathrm{~mm}$ free BAPTA and EGTA on the fast secretory component. Ten cells were investigated under each condition, using the same protocol as depicted in Figures 2 and 3.

Both the amplitude and the time constant of the fast exponential component were slightly altered by EGTA $(\sim 28 \mathrm{fF}$ and 8 msec, respectively, as compared with $42 \mathrm{fF}$ and $7 \mathrm{msec}$ at low buffering conditions). In contrast, the fast secretory component was hardly detectable in cells dialyzed with BAPTA (Fig. 5A). The delayed rise of $\Delta C_{\text {exo }}$ in cells dialyzed with BAPTA most likely represents recruitment of vesicles after the chelator became locally increasingly saturated by the incoming $\mathrm{Ca}^{2+}$. Responses to longer depolarizations were comparable between EGTA- and BAPTA-buffered cells but smaller than those observed at low buffering conditions, indicating that both buffers similarly suppress the slow secretory component. A plot of $\Delta C_{\text {exo }}$ versus $Q_{\mathrm{Ca}}$ 


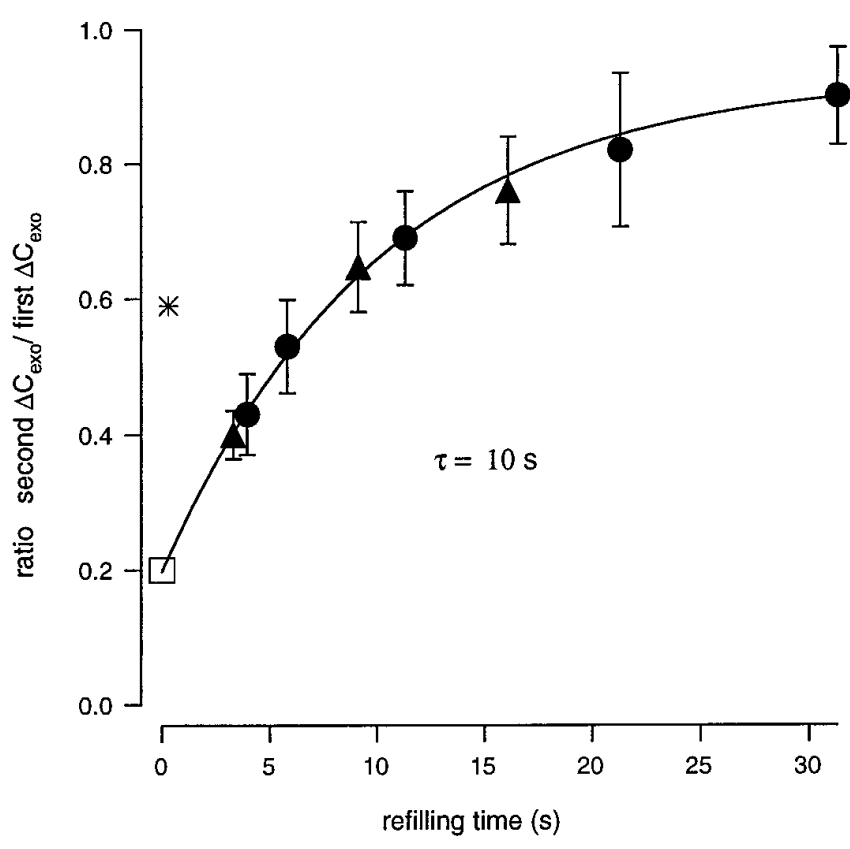

Figure 6. Recovery time course of the fast secretory component in mouse chromaffin cells in slices. The ratio of $\Delta C_{\text {exo }}$ caused by two identical 20 msec depolarizations (ratio of the second over the first $\Delta C_{\text {exo }}$ ) is plotted versus the separation times of the two stimuli. Intervals of $30 \mathrm{sec}$ or more were allowed between the pairs of stimuli for complete recovery of the fast secretory component. The filled triangles represent ratios of responses to accordingly separated, individual $20 \mathrm{msec}$ depolarizations to $0 \mathrm{mV}$. The data were obtained in five cells from two preparations (pipette solution B, external solution 1). $\Delta C_{\text {exo }}$ was estimated by approach 1 in Materials and Methods. The filled circles represent data from a different set of eight cells in which we applied pairs of dual pulses at varying separation times (configuration of the dual pulses as described in Fig. 4, pipette solution B, external solution 1). $\Delta C_{\text {exo1 }}$ of the second and the first dual pulses (estimated as described in Fig. 4) were related to each other. The fit to the pooled ratios from both sets of experiments revealed a recovery time constant of $10 \mathrm{sec}$. Back-extrapolation to $0 \mathrm{sec}$ separation time indicates that the maximum depletion by the first stimulus was $80 \%$ (empty square). For comparison, the star symbol represents the mean ratio $\Delta C_{\text {exo2 }}$ over $\Delta C_{\text {exo1 }}$ within a dual pulse (300 msec separation, $40 \%$ depletion) determined for the same experiments.

(Fig. $5 B$ ) shows a small inflection for the case of BAPTA at small $Q_{\mathrm{Ca}}$ values, but otherwise is quite similar in shape to the $\Delta C_{\text {exo }}$ pulse duration plot for both chelators (Fig. $5 A$ ).

\section{Recovery of the fast secretory component in slices (pool refilling)}

We investigated the recovery time course of the fast secretory component by comparing $\Delta C_{\text {exo }}$ for two "pool-depleting" depolarizations $(20 \mathrm{msec})$ separated by different intervals. Figure 6 shows the time course of recovery with $300 \mathrm{nM}\left[\mathrm{Ca}^{2+}\right]_{\text {free }}$ in the pipette. The symbols represent ratios of second over first $\Delta C_{\text {exo }}$ responses. Secretion was elicited either by separated individual depolarizations (triangles) or by separated dual pulses (circles; the dual pulses had the same configuration as depicted in Fig. 4). In the latter case, ratios were calculated for the first depolarizations $\left(\Delta C_{\text {exo1 }}\right.$; see Fig. 4) of the two separated dual pulses. Pool refilling measured in both ways is quite similar and well fitted by a single exponential with a time constant of $\sim 10 \mathrm{sec}$ (pooled data from 13 cells, seven preparations). Back-extrapolation to time 0 gave a ratio of 0.2 (empty square in Fig. 6), indicating $80 \%$ pool depletion for the first stimulus.

If a first-order kinetic scheme can be assumed for the pool refilling, as indicated by the mono-exponential time course, then the maximal refilling rate is given by the product of the recovery rate constant $(1 / \tau)$ and the pool size. Applying the dual-pulse analysis (see above) to each first of the separated dual pulses (which recruited the completely filled pool in these experiments), we estimated the lower $\left(\Delta C_{\text {exo1 }}\right)$ and upper pool size bounds $\left(B_{\max }\right)$ to be $25.4 \pm 2.35 \mathrm{fF}$ and $55.7 \pm 4.8 \mathrm{fF}$, respectively $(n=26$ pulses from eight cells). Taking $\Delta C_{\text {exo } 1}, B_{\text {max }}$, and the refilling rate constant, we calculated lower and upper bounds for the maximal refilling rate as 2.5 and $5.6 \mathrm{fF} / \mathrm{sec}$, respectively.

\section{DISCUSSION}

Chromaffin cells in situ can secrete in response to individual APs. We demonstrated that this rapid exocytosis is from a small pool of vesicles that probably experience a very high $\left[\mathrm{Ca}^{2+}\right]$ during the stimulation. Furthermore, the characterization of secretion kinetics for wild-type mouse adrenal chromaffin cells lays the foundations for future comparison with transgenic mice.

\section{Kinetic components of depolarization-induced secretion in mouse chromaffin cells in slices}

\section{Fast secretory component}

When voltage step depolarizations of varying duration are applied to mouse chromaffin cells in slices, a rapid secretory component is observed that can be well separated from a slower secretory component. The fast component most likely represents a pool of vesicles similar in size ( $42 \mathrm{fF}$ ) to rapidly recruited pools found in isolated rat chromaffin cells (33.9 fF) (Horrigan and Bookman, 1994), isolated bovine chromaffin cells (34 fF) (Gillis et al., 1996), and peptidergic nerve terminals in slices of the rat posterior pituitary (40 fF) (Hsu and Jackson, 1996). The size of our fast secretory component also falls well into the range for the pool size derived from the dual-pulse analysis (25-73 fF) in our slice preparation.

The recovery time constant of the rapidly recruited pool in our slice preparation $(10 \mathrm{sec})$ is in good agreement with time constants of pool refilling in other preparations. Thus, Stevens and Tsujimoto (1995) obtained a time constant of $10 \mathrm{sec}$ for synapses of cultured hippocampal neurons, and a time constant of $8 \mathrm{sec}$ was measured in bipolar terminals by von Gersdorff and Matthews (1997). The time needed for complete recovery $(\sim 3 \tau)$ of the fast secretory component in our slice preparation (with $\left[\mathrm{Ca}^{2+}\right]_{\mathrm{i}}$ buffered to $300 \mathrm{~nm}$ ) is slightly shorter than that required for complete pool refilling in bovine adrenal chromaffin cells $(60 \mathrm{sec}$, without addition of $\mathrm{Ca}^{2+}$-loaded buffers to the pipette solution) (von Rüden and Neher, 1993). This difference could well be caused by the slightly elevated $\left[\mathrm{Ca}^{2+}\right]_{\mathrm{i}}$ in our experiments, because refilling is $\mathrm{Ca}^{2+}$ dependent (von Rüden and Neher, 1993).

\section{Slow secretory component}

We did not explore the slow secretory component in detail. Although we cannot exclude that it represents a fast delivery or priming process, we favor the idea that longer $\mathrm{Ca}^{2+}$ injections lead to a spatially more extended rise in submembrane $\left[\mathrm{Ca}^{2+}\right]$ and thereby recruit fusion-competent vesicles located at greater distances from the $\mathrm{Ca}^{2+}$ channels. The rate of pool recovery (upper boundary: $5.6 \mathrm{fF} / \mathrm{sec}$ ) is almost 50 times smaller than the slope of the slow $C_{\mathrm{m}}$ rise $(270 \mathrm{fF} / \mathrm{sec})$. Even though $\left[\mathrm{Ca}^{2+}\right]_{\mathrm{i}}$ is higher during a pulse (when the slow secretory component is measured) than between pulses (as in the recovery experiments), it seems unlikely to us that the supply rate could increase fiftyfold because of an increased $\left[\mathrm{Ca}^{2+}\right]$. Thus, it was concluded from experiments 
in which catecholamine secretion was triggered by dialysis with high $\left[\mathrm{Ca}^{2+}\right]$ that the vesicle delivery rate may be half-maximal already at a $\left[\mathrm{Ca}^{2+}\right]_{\mathrm{i}}$ of $1.2 \mu \mathrm{M}$ (Heinemann et al., 1993).

The concept of a "releasable pool" implies a set of vesicles in the same state of fusion competence; however, spatial heterogeneity of the $\mathrm{Ca}^{2+}$ signal during membrane depolarization can divide a pool of vesicles with homogeneous fusion competence into kinetically distinct subpools (Horrigan and Bookman, 1994). The fractions of vesicles comprising the fast and slow secretory components described here might represent subpools of a large readily releasable pool. This large pool was presumably only marginally depleted by our maximal stimuli.

Thus, at least two kinetic components might ensure catecholamine release over a wide range of splanchnic nerve activities. Release at low chromaffin cell AP frequencies will be mediated by the small fast pool, whereas the large slow secretory component is probably recruited during stronger stimulation.

\section{The fast kinetics of secretion in mouse chromaffin cells in slices suggests close spatial coupling of release sites and $\mathrm{Ca}^{2+}$ channels}

The average initial secretory rate for mouse chromaffin cells in slices $(7300 \mathrm{fF} / \mathrm{sec})$ is much faster than that obtained for isolated mouse $(1300 \mathrm{fF} / \mathrm{sec})$, rat $(680 \mathrm{fF} / \mathrm{sec})$ (Horrigan and Bookman, 1994), and bovine ( $860 \mathrm{fF} / \mathrm{sec}$ ) (Chow et al., 1994) chromaffin cells. We conclude that a fast release kinetics rather than a large pool underlies the high secretory rate in mouse chromaffin cells in slices, because their fast secretory component compares well in size with rapidly secreted pools described previously for isolated chromaffin cells (see above). High average secretory rates have also been obtained from peptidergic nerve terminals in slices of the posterior pituitary (Hsu and Jackson, 1996). The different kinetics in mouse chromaffin cells in slices and in primary culture are not simply attributable to the larger $\mathrm{Ca}^{2+}$ currents in slices, because cells in slices show more secretion for a given amount of $\mathrm{Ca}^{2+}$ entry when the responses to short depolarizations are compared (Fig. 3B). Possible explanations for the faster release kinetics in chromaffin cells in slices include (1) higher [Ca] at the release sites because of particular spatial arrangements of $\mathrm{Ca}^{2+}$ channels and release sites, (2) higher [Ca] at the release sites in slices caused by contribution of fast calcium-induced calcium release (CICR) present only in the slice preparation, and (3) different $\mathrm{Ca}^{2+}$ dependencies of secretion in slice and isolated cells.

Possibilities (2) and (3) are unlikely. When we intracellularly applied ruthenium red, an inhibitor of CICR (Miyamato and Racker, 1982), rapid exocytosis remained unaffected (50 $\mu \mathrm{M}$ in the presence of $1 \mathrm{~mm}$ free EGTA; data not shown), ruling out a major contribution of CICR. Regarding possibility (3), it seems important to note that the amount of secretion in slice and isolated cells was clearly distinguishable only for small amounts of $\mathrm{Ca}^{2+}$ influx. Therefore, one would have to postulate that only the fast release component is more sensitive to $\left[\mathrm{Ca}^{2+}\right]$ in slices, whereas the slow component shares the same (low) $\mathrm{Ca}^{2+}$ sensitivity with the isolated cells.

We favor the interpretation that the $\mathrm{Ca}^{2+}$ sensors of a fraction of release sites in chromaffin cells in slices experience a very high $\left[\mathrm{Ca}^{2+}\right]$ because of their close spatial relation to the $\mathrm{Ca}^{2+}$ channels [possibility (1)]. A global elevation of $\left[\mathrm{Ca}^{2+}\right]_{\mathrm{i}}$ of $40-80 \mu \mathrm{M}$ by flash photolysis in bovine chromaffin cells (Heinemann et al., 1994) provides a vesicle release rate constant comparable to the average value in slices $\left(140 \mathrm{sec}^{-1}\right)$. Buffering $\left[\mathrm{Ca}^{2+}\right]_{\mathrm{i}}$ with BAPTA strongly decreased the fast secretory component. The different effects of equimolar concentrations of BAPTA and EGTA on the fast secretory component in mouse chromaffin cells in slices suggest that $\mathrm{Ca}^{2+}$ is trapped by the $\mathrm{Ca}^{2+}$ sensor of the release site before $\mathrm{Ca}^{2+}$ binding to the chelators has reached an equilibrium. This is taken as additional support for short diffusional distances between $\mathrm{Ca}^{2+}$ channels and release sites.

Possible explanations for a high $\left[\mathrm{Ca}^{2+}\right]$ at the release sites with $\mathrm{Ca}^{2+}$ originating solely from $\mathrm{Ca}^{2+}$ entry include clustering of $\mathrm{Ca}^{2+}$ channels with or without co-clustering of release sites and molecular coupling of release sites and $\mathrm{Ca}^{2+}$ channels. The polarized phenotype of chromaffin cells in situ (Carmichael, 1986) certainly motivates speculation of a co-clustering of "exocytotic" $\mathrm{Ca}^{2+}$ channels and release sites at the capillary pole (Michelena et al., 1995), which then would favor directional catecholamine release into the capillaries. Robinson et al. (1995) reported overlap of hotspots of submembrane $\left[\mathrm{Ca}^{2+}\right]$ and of secretion in isolated bovine chromaffin cells and argued for release from active zonelike structures in these cells. On the other hand, Robinson et al. (1995) acknowledged that hotspots of submembrane $\left[\mathrm{Ca}^{2+}\right]$ were seen only in a fraction of cells. Furthermore, functional studies on the same preparation indicated that the majority of the release sites is located, on average, several hundreds of nanometers away from the nearest channel (Klingauf and Neher, 1997). The two findings can be accommodated if it is assumed that morphological specializations, which exist in situ, are preserved only to a variable extent in primary culture. The different secretion kinetics observed for slice and isolated cells in the present study support this assumption.

Molecular coupling has been demonstrated for syntaxins with $\mathrm{N}$ - and P/Q-type $\mathrm{Ca}^{2+}$ channels (Bennett et al., 1992; Rettig et al., 1996). To our knowledge, however, no data are available showing to what extent $\mathrm{Ca}^{2+}$ influx through different $\mathrm{Ca}^{2+}$ channel types triggers secretion in mouse chromaffin cells in situ or in isolation. Whether the high $\left[\mathrm{Ca}^{2+}\right]$ at release sites of chromaffin cells in slices during depolarization is attributable to molecular coupling of release sites to $\mathrm{Ca}^{2+}$ channels or to segregation of $\mathrm{Ca}^{2+}$ channels into specialized regions of the plasma membrane remains to be clarified.

\section{REFERENCES}

Adler EM, Augustine GJ, Duffy SN, Charlton MP (1991) Alien intracellular calcium chelators attenuate neurotransmitter release at the squid giant synapse. J Neurosci 11:1496-1507.

Augustine GJ, Neher E (1992) Calcium requirements for secretion in bovine chromaffin cells. J Physiol (Lond) 450:247-271.

Bennett MK, Calakos N, Scheller RH (1992) Syntaxin: a synaptic protein implicated in docking of synaptic vesicles at presynaptic active zones. Science 257:255-259.

Burgoyne RD (1995) Fast exocytosis and endocytosis triggered by depolarisation in single adrenal chromaffin cells before rapid $\mathrm{Ca}^{2+}$ current run-down. Pflügers Arch 430:213-219.

Carmichael SW (1986) Morphology and innervation of the adrenal medulla. In: Stimulus-secretion coupling, Vol 1, (Rosenheck K, Lelkes P, eds), pp 1-29. Boca Raton, FL: CRC.

Carmichael SW, Brooks JC, Malhotra RK, Wakade TD, Wakade AR (1989) Ultrastructural demonstration of exocytosis in the intact rat adrenal medulla. J Electron Microsc Tech 12:316-322.

Chow RH, Klingauf J, Neher E (1994) Time course of $\mathrm{Ca}^{2+}$ concentration triggering exocytosis in neuroendocrine cells. Proc Natl Acad Sci USA 91:12765-12769.

Chow RH, Klingauf J, Heinemann C, Zucker RS, Neher E (1996) Mechanisms determining the time course of secretion in neuroendocrine cells. Neuron 16:369-376.

Douglas WW (1968) Stimulus-secretion coupling: the concept and clues from chromaffin cells and other cells. Br J Pharmacol 34:453-474. 
Gillis KD, Mößner R, Neher E (1996) Protein kinase C enhances exocytosis from chromaffin cells by increasing the size of the readily releasable pool of secretory granules. Neuron 16:1209-1220.

Gilly WF, Armstrong CM (1980) Gating current and potassium channels in the giant axon of the squid. Biophys J 29:485-492.

Hamill OP, Marty A, Neher E, Sakmann B, Sigworth F (1981) Improved patch clamp techniques for high resolution current recordings from cells and cell-free membrane patches. Pflügers Arch 391:85-100.

Heinemann C, von Rüden L, Chow RH, Neher E (1993) A two-step model of secretion control in neuroendocrine cells. Pflügers Arch 424:105-112.

Heinemann C, Chow RH, Neher E, Zucker RS (1994) Kinetics of the secretory response in bovine chromaffin cells following flash photolysis of caged $\mathrm{Ca}^{2+}$. Biophys J 67:2546-2557.

Horrigan FT, Bookman RJ (1993) Na channel gating charge movement is responsible for the transient capacitance increase evoked by depolarization in rat adrenal chromaffin cells. Biophys J 64:101A.

Horrigan FT, Bookman RJ (1994) Releasable pools and the kinetics of exocytosis in adrenal chromaffin cells. Neuron 13:1119-1129.

Hsu S-F, Jackson MB (1996) Rapid exocytosis and endocytosis in nerve terminals of the rat posterior pituitary. J Physiol (Lond) 494.2:539-553.

Katz B (1969) The release of neural transmitter substances. Liverpool, UK: Liverpool UP.

Katz B, Miledi R (1965) The measurement of synaptic delay, and the time course of acetylcholine release at the neuromuscular junction. Proc R Soc Lond [Biol] 161:483-495.

Kidokoro Y, Ritchie AK (1980) Chromaffin cell action potentials and their possible role in adrenalin secretion from the rat adrenal medulla. J Physiol (Lond) 307:199-216.

Klingauf J, Neher E (1997) Modelling buffered $\mathrm{Ca}^{2+}$ diffusion near the membrane: implications for secretion in neuroendocrine cells. Biophys J 72:674-690.

Michelena P, Vega T, Montiel C, Lopez MG, Garcia-Perez LE, Gandia L, Garcia AG (1995) Effects of tyramine and calcium on the kinetics of secretion in intact and electroporated cells superfused at high speed. Pflügers Arch 431:283-296.

Miyamato H, Racker E (1982) Mechanism of calcium release from skeletal sarcoplasmatic reticulum. J Membr Biol 66:193-201.

Neher E (1988) The influence of intracellular calcium concentration on degranulation of dialysed mast cells from rat peritoneum. J Physiol (Lond) 395:193-214.
Neher E, Marty A (1982) Discrete changes in cell membrane capacitance observed under conditions of enhanced secretion in bovine adrenal chromaffin cells. Proc Natl Acad Sci USA 79:6712-6716.

Park YB (1994) Ion selectivity and gating of small conductance $\mathrm{Ca}^{2+}$. activated $\mathrm{K}^{+}$channels in cultured rat adrenal chromaffin cells. J Physiol (Lond) 481:555-570.

Rettig J, Sheng Z-H, Kim DK, Hodson CD, Snutch TP, Caterall WA (1996) Isoform-specific interaction of the $\alpha_{1 \mathrm{a}}$ subunits of brain $\mathrm{Ca}^{2+}$ channels with the presynaptic proteins syntaxin and SNAP-25. Proc Natl Acad Sci USA 93:7363-7368.

Robinson IM, Finnegan JM, Monck JR, Wightman RM, Fernandez JM (1995) Colocalization of calcium entry and exocytotic release sites in adrenal chromaffin cells. Proc Natl Acad Sci USA 92:2474-2478.

Seward EP, Nowycky MC (1996) Kinetics of stimulus-coupled secretion in dialyzed bovine chromaffin cells in response to trains of depolarizing pulses. J Neurosci 16:553-562.

Stevens CF, Tsujimoto T (1995) Estimates for the pool size of releasable quanta at a single central synapse and for the time required to refill the pool. Proc Natl Acad Sci USA 92:846-849.

Thomas P, Wong JG, Lee A, Almers W (1993) A low affinity $\mathrm{Ca}^{2+}$ receptor controls the final steps in peptide secretion from pituitary melanotrophs. Neuron 11:93-104.

Thomas-Reetz AC, De Camilli P (1994) A role of synaptic vesicles in non-neuronal cells: clues from pancreatic beta cells and from chromaffin cells. FASEB J 8:209-216.

von Gersdorff H, Matthews G (1994) Dynamics of synaptic vesicle fusion and membrane retrieval in synaptic terminals. Nature 367:735-739.

von Gersdorff H, Matthews G (1997) Depletion and replenishment of vesicle pools at a ribbon-type synaptic terminal. J Neurosci 17: 1919-1927.

von Rüden L, Neher E (1993) A Ca-dependent early step in the release of catecholamines from adrenal chromaffin cells. Science 262: 1061-1065.

Wakade AR (1982) Studies on secretion of catecholamines evoked by acetylcholine or transmural stimulation of the rat adrenal gland. J Physiol (Lond) 313:463-480.

Zhou Z, Misler S (1995) Action potential-induced quantal secretion of catecholamines from rat adrenal chromaffin cells. J Biol Chem 270: $3498-3505$. 